Equilibrium : Jurnal Pendidikan

Vol. VIII. Issu 1. Januari-Juni 2020

\title{
Pelestarian Nilai Budaya Kaco'i Angi Pada Masyarakat Donggo
}

\author{
Sumitro \\ Dosen Sosiologi, Institut Ilmu Sosial dan Ilmu Budaya Samawa Rea \\ Email: sumitro.sosiologi@yahoo.com
}

\begin{abstract}
Preservation of the culture of kaco'i angi culture is another form of the term mutual respect or socalled tolerance. This type of research is a qualitative description research. This study aims to find out more comprehensively about the meaning that is contained in the culture of angi's culture in the Donggo community. The results of this study reveal that angi's kaco'i is not just a slogan of respect for each other, but rather emphasizes the process of instilling morality in the next generation and becomes a life guide for the Donggo generation in living in society, both within their own communities and in the wider community. So by internalizing the value of angi's cocoa, the next generation of Donggo will certainly be able to blend quickly with the community wherever they are.
\end{abstract}

Keywords: Preservation, Cultural Values, Kaco'l Angi, Society.

Abstrak. Pelestarian nilai budaya kaco'i angi merupakan bentuk lain dari istilah saling menghargai antar sesama atau yang disebut toleransi.Jenis penelitian yang digunakan adalah penelitian deskripsi kualitatif.Penelitian ini bertujuan untuk mengetahui lebih komprehensif tentang makna yang terkandung dalam nilai budaya kaco'l angi pada masyarakat Donggo.Hasil penelitian ini mengungkapkan bahwa kaco'i angi bukan sekedar slogan menghormati antar sesama, tetapi lebih menekankan pada proses penanaman nilai moralitas pada generasi penerus serta menjadi pegangan hidup bagi generasi Donggo dalam hidup di masyarakat, baik dilingkungan masyarakatnya sendiri maupun di masyarakat yang lebih luas. Sehingga dengan internalisasi nilai kaco'i angi tersebut generasi penerus Donggo dipastikan bisa membaur dengan cepat dengan masyarakat dimanapun mereka berada.

Kata Kunci : Pelestarian, Nilai budaya, Kaco'i Angi, Masyarakat.

\section{PENDAHULUAN}

Suku Donggo yang ada di kabupaten Bima dalam literatul sejarah masyarakat Bima dianggap sebagai suku tertua. Suku Donggo hidup di lereng gunung mboha yang mata pencarian masyarakatnya adalah bertani. Suku Donggo yang sekarang bernama kecamatan Donggo di diami oleh tiga agama diantaranya adalah Islam, Kristen, dan Khatolik. Kemajemukkan dalam aspek keyakinan tersebut menjadi ancaman terjadinya disintegrasi antara ummat beragama yang akhirakhir ini membela politik kita dalam skala nasional. Jika hal itu tidak dikelola secara bijak maka ia akan menjadi bibit terjadinya konflik yang berkepanjangan.

Masyarakat Donggo adalah masyarakat yang masih menjadikan kebudayaan sebagai pijakan dasar dalam menyusun dan merawat toleransi antar ummat beragama. Toleransi antar ummat beragama di masyarakat Donggo karena mereka masih menghidupkan budaya kaco'i angi. Adapun arti kaco'i angi dapat dibagi dengan dua kata kaco'i artinya penghargaan dan angi artinya persaudaraan. Jadi kaco'i angi adalah sikap menghargai dalam aspek persaudaraan. Kata persaudaraan yang dipahami oleh masyarakat Donggo bukan saudara kandung tapi saudara 
kebudayaan. Artinya persaudaraan yang diikat oleh persamaan bahasa, tempat tinggal dan nenek moyang yang sama.

Di kalangan masyarakat Kecamatan Donggo ada beberapa keluarga yang didalamnya penganut agama yang berbeda-beda. Perbedaan keyakinan tersebut tidak menyebabkan keluarga mereka bermasalah. Perbedaan keyakinan bagi orang Donggo adalah medan untuk menunjukkan kebaikan agamanya masing-masing. Karena semua agama Donggo ajaran kasih dan untuk menguji ketahanan keyakinan seseorang terhadap agamanya yang di butuhkan adalah kehadiran keyakinan lain yang hidup di tengah-tengah mereka.

Kaco'i angi adalah bentuk lain dari toleransi antara umat beragama, bukanlah sesuatu yang dapat dicampuradukan, melainkan mewujudkan ketenangan, saling menghargai, bahkan sebenarnya lebih dari itu, antar pemeluk agama harus dibina untuk gotong-royong dalam membangun masyarakat yang memiliki ahlak dalam bertingkah laku, bertutur kata demi terciptanya kebahagiaan dalam kehidupan bersama.

Toleransi antar umat beragama kalau di lihat secara realitas yang terjadi dilapangan maka sikap toleransi antar umat beragama sudah tidak bermakna lagi dalam kehidupan masyarakat Indonesia dan sudah bermakna lain karena seiring dengan perubahan sosial maka akan merubah keadaan masyarakat pada suatu keadaan yang baru, (Hanani Silfian, $2013: 43$ ).

Kalau di analisa dengan teorinya Emile Durkheim tentang agama bahwa agama merupakan perwujudan dari collective consciousness (kesadaran kolektif) sekalipun selalu ada perwujudaanperwujudan lainnya. agama merupakan sarana yang dianggap berperan dalam menciptakan kesadaran kolektif di antara masyarakat, atau dengan kata lain ritual agama merupakan charge bagi manusia untuk mendekatkan diri kembali kepada Tuhannya. Agama juga sebagai suatu sistem kepercayaan dan tingkah laku yang berhubungan dengan hal-hal yang dianggap sakral yaitu merupakan hal-hal yang dilarang dan dipisahkan, kepercayaan dan perilaku yang mempersatukan semua penganutnya menjadi satu komunitas moral, yaitu berdasarkan nilai-nilai bersama yang disebut umat. Jadi jelas bahwa toleransi antar umat beragama merupakan suatu bentuk kesadaran kolektif untuk mengikat dan mempersatukan masyarakat dalam keteraturan sosial.

Dalam UUD 1945 Jaminan konstitusi terhadap kebebasan beragama di Indonesia ditegaskan dalam pasal $28 \mathrm{E}$ ayat (1) dan ayat (2) bahwa, "Setiap orang bebas memeluk agama dan beribadat menurut agamanya." Bahwa, " Setiap orang berhak atas kebebasan meyakini kepercayaan, menyatakan pikiran dan sikap sesuai dengan hati nuraninya." Jaminan ini diperkuat lagi dalam pasal 29 ayat (2) UUD 1945, yang menyebutkan bahwa "Negara menjamin kemerdekaan tiap- tiap penduduk untuk memeluk agamanya masing-masing dan untuk beribadat menurut agamanya dan kepercayaannya itu."

Kerukunan antar umat beragama adalah hal yang sangat penting dalam kehidupan masyarakat Kecamatan Donggo untuk mencapai sebuah kesejahteraan hidup. Toleransi antar umat beragama sebagai salah satu pola pikir yang di implemetasi oleh masyarakat Kecamatan Donggo untuk mewujudkan masyarakat yang ta'at terhadap perintah juga larangan tuhan yang maha ESA, dan sebagai contoh bagi Desa-Desa yang lain yang ada di Kecamatan Donggo Kabupaten Bima maupun di luar Kecamatan Donggo Kabupaten Bima.

Perwujudan bentuk kaco'i angi antar umat beragama di Kecamatan Donggo Kecamatan Donggo Kabupaten Bima di antaranya memahami setiap perbedaan, sikap saling tolong menolong antar sesama umat beragama. Jadi masyarakat Kecamatan Donggo memiliki pandangan seperti pandangan umat islam, atau pandangan-pandangan umat beragama yang lain, kecuali dalam hal keyakinan mereka tidak boleh karena agama islam melakukan ibadah sesuai dengan saryi'at islam, khatolik beribadah sesuai dengan ajaran khatoliknya begitu juga dengan agama protestan beribadah sesuai dengan ajaran agamanya tapi dalam kehidupan sosial mereka sangat menghargai dan menghormati. Sesuai dengan pengamatan awal bahwa di satu sisi juga terwujudnya bentuk kaco'i angi antar umat beragama di Kecamatan Donggo karena ada unsur keturunan.

Bentuk-bentuk kaco'i angi antar umat beragama di Kecamatan Donggo di antaranya saling menghargai, saling menghormati, saling membantu, saling tolong menolong antara agama yang satu 
dengan agama yang lainnya, bentuk toleransi ini merupakan pola pikir yang di bentuk oleh masyakat Kecamatan Donggo dari sejak masyarakat mengetahui akan suatu perbedaan itu hal yang paling lumrah. Contoh dari bentuk kaco'i angi antar umat beragama di Kecamatan Donggo antara lain sebagai berikut: ketika ada acara pernikahan maka semua masyarakat Kecamatan Donggo baik yang islam, khatolik, maupun protestan ikut terlibat dalam acara atau kegiatan tersebut dalam artian untuk saling membantu, saling tolong menolong, seperti dalam membentuk panitia pernikahan, membangun pelaminan pernikahan, atau kegiatan yang berkaitan dengan sosial.

Bentuk kaco'i angi yang paling menonjol dan yang dapat mengikat masyarakat Kecamatan Donggo adalah Rawi Rasa, Tekarane,e dan Mbolo Weki. Kaco'i angi yang seperti ini yang masih melekat dalam diri masyarakat tersebut. Masyarakat Kecamatan Donggo walaupun didalam kehidupan memiliki keyakinan yang berbeda-beda, bahkan dalam satu keluarga terdapat tiga penganut agama. Karena budaya kaco'i angi menyebabkan satu keluarga yang berbeda keyakinan dapat hisdup rukun dan saling menghormati atas perbedaan yang mereka pilih. Contoh bentuk kaco'i angi pada masayarakat kecamatan Donggo dapat kita lihat ketika perayaan hari besar agama. Ketika bulan puasa masyarakat non-muslim tidak makan atau merokok di tempat-tempat terbuka. Atau ketika hari pernikahan keluarga non-muslim yang menyembelih sapi atau kambilng serta memasak dan makanan dilakukan oleh masyarakat yang beragama muslim.

Kenyataan inilah yang menjadi bahan kajian yang sangat menarik dan di teliti lebih mendalam supaya masalahan dalam umat beragama yang masih kabur bisa di ungkapkan secara detail sehinggga Analisis Bentuk kaco'l angi atau Toleransi Antar Umat Beragama di Kecamatan Donggo Kabupaten Bima tetap ada dan tumbuh dalam kehidupan masyarakat.

\section{A. Budaya Kaco'i Angi atau toleransi}

Menurut Umar Hasyim, toleransi yaitu pemberian kebebasan kepada sesama manusia atau kepada sesama warga masyarakat untuk menjalankan keyakinannya atau mengatur hidupnya dan menentukan nasibnya masing-masing, selama dalam menjalankan dan menentukan sikapnya itu tidak melanggar dan tidak bertentangan dengan syarat-syarat atas terciptanya ketertiban dan perdamaian dalam masyarakat. Namun menurut W. J. S. Poerwadarminto, toleransi adalah sikap/sifat menenggang berupa menghargai serta memperbolehkan suatu pendirian, pendapat, pandangan, kepercayaan maupun yang lainnya yang berbeda dengan pendirian sendiri, (W. J. S. Poerwadarminto, 1986 : 184).

Toleransi yang diuraikan diatas merupakan salah satu bentuk hak asasi manusia diberikan kebebasan kepada orang lain atau kepada manusia yang satu dengan manusia yang lainnya atau kepada masyarakat yang berbeda pendapat, berbeda keyakinan supaya mereka tersebut bisa meyakini keyakinan masing-masing, karena kita yang memiliki tempat tinggal yang berbeda-beda, memiliki pendapat yang berbeda-beda atau memiliki keyakinan yang berbeda-beda, jadi untuk mempersatukan perbedaan tersebut tentu kita harus saling menghargai dan mengormati antara satu sama lain.

Toleransi antar umat beragama yang telah diuaraikan mencakup suatu keyainan yang berbeda, atau akidah yang berbeda-beda tentu kita harus memberikan kebebasan kepada kelompok yang minoritas supaya bisa mengekspresikan dirinya untuk memeluk agama yang diyakininya supaya tidak terjadi perselisihan atau konflik antara umat agama. Contohnya bentuk toleransi antar umat beragama, dimana penganut mayoritas dalam suatu masyarakat mengizinkan keberadaan agamaagama lainnya. Ketika ada suatu hajatan misalnya pernikahan orang muslim maka agama yang lain akan saling membantu, kalaupun ada kekurangan dalam keuangan atau yang lain mereka akan melengkapi apa yang menjadi kekurangan tersebut, inilah bentuk dari toleransi antara umat beragama.

Toleransi antar agama sejatinya masing-masing agama harus saling memahami bagaimana ajaran konsep toleransi pada agama mereka, agar tecipta kerukunan antar agama tanpa bertentangan dengan ajaran yang diajarkan oleh agama itu sendiri, dan tanpa menyalahi aqidah agama masing-masing yang dianut. 
1) Dasar persamaan

Persamaan sebagai pertalian kebabasan didalam hak asasi manusia. Persamaan yang di maksud adalah persamaan dalam hal hak-hak dan kewajiban dari segi dasar, tampa membedakan kewarganegaraan, daerah asal, warna kulit, keyakinan agama maupun kecondangan politik.

2). Advertensi hak-hakKristen, islam dan semua organisasi modern terfokus pada stabilitas pondasi keselamatan didunia, mewuudkan keselamatan sosial dalam setiap Negara, membuang rasa irih, dan dendam, mejalin huungan diantara manusia atas dasar kasih sayang dan ramah, bekerja sama dan saling mencintai, persaudaraan humanistik.

3) Sistem pemisahan antara kekuasaan tujuannya agar tidak ada rangkap kekuasaan dan fokusnya kekuasaan dalam menghendel seseorang maupu satu lembaga.

4) Pengontrolan judicial terhadap konstitusional undang-undang yaitu jaminan yang efektif untuk memelihara hak-hak induvidu dan kebebasannya, tidak adanya penindasan kekuasaan penguasa terhadap hak maupun kebebasan individu.

\section{Fungsi Kaco'i Angi antar umat beragama}

Fungsi toleransi antar umat beragama antara lain sebagi berikut :

a. Menghindari Perpecahan

Negara plural seperti negara Indonesia, merupakan negera yang rentan terjadinya perpecahan. Hal ini juga dikarenakan di Indonesia mudah merebaknya isu keagamaan. Maka dari itu dengan sadar dan benar-benar menerapkan nilai toleransi, bangsa Indonesia mampu menghindari perpecahan terutama yang berkaitan mengenai agama.

b. Mempererat hubungan antar umat beragama

Toleransi beragama juga memiliki fungsi mempererat hubungan beragama. Karena dalam toleransi beragama mengajarkan kesadaran menerima perbedaan, antar umat beragama bisa saling bahu membahu dalam menciptakan perdamaian yang merupakan cita-cita dari semua umat manusia. Masyarakat dan negara juga bisa saling mendukung tercapainya kehidupan yang harmoni melalui toleransi beragama.

c. Meningkatkan ketaqwaan

Semakin memahami tentang prinsip agama masing-masing, semakin pula menyadarkan akan nilai toleransi. Karena semua agama mangajarkan hal yang baik penuh dengan rasa kasih sayang baik sesama umat maupun yang berbeda keyakinan. Tak ada satupun agama yang mengajarkan tentang pertikaian. Bagaimana mengatur hubungan dengan masyarakat yang beragama lain. Ketaqwaan seseorang pun dapat terlihat dari bagaimana cara manusia menerapkan ajaran agamanya masing-masing.

d. Meningkatkan rasa persaudaraan

Sikap toleransi dapat menimbulkan rasa sayang dan meningkatakan rasa persaudaraan antara umat beragama. kondisi ini dapat membuat terhindar adanya kesalahpahaman dan pertikaian yang tidak perlu.

e. Meruntuhkan rasa paling benar pada diri sendiri

Tidak ada satu manusiapun yang akan luput dari yanag namanya kesalahan ataupun kekurangan. sikap toleransi akan menghindari seseorang untuk bersikap egois dan merasa diri paling benar. sikap toleransi dapat membuat manusia lebih cerdas dalam berfikir positif.

\section{B. Umat beragama}

Umat beragama adalah sekumpulan manusia yang memiliki hubungan sesama umat beragama yang dilandasi dengan toleransi, saling pengertian, saling menghormati, saling menghargai dalam kesetaraan pengamalan ajaran agamanya dan kerja sama dalam kehidupan masyarakat dan bernegara. (Nahariyanti, 2013:56).

Umat beragama merupakan orang atau seseorang yang percaya kepada tuhan dengan keyakinan bahwa tuhanlah yang telah menciptakan alam semesta dengan segalah isinya termasuk 
manusia itu sendiri, di katakan sebagai Umat beragama karena ada kekuatan yang lebih tinggi di luar kemampuan manusia yaitu tuhan. Dalam umat beragama terdapat beberapa agama yang di anut atau yang di yakini oleh seseorang meliputi: Agama Islam, Agama Protestan, Agama Katolik, Agama Budha, agama Hindu, dan Agama Konghucu.

Seperti masyarakat yang ada di Kecamatan Donggo Kabupaten Bima yang memiliki umat beragama yang berbeda keyakinan, umat beragama di antaranya islam, katolik, protestan, dimana ketiga umat beragama ini bisa hidup bersama dan berdampingan di satu desa. Toleransi antar umat beragama di Kecamatan Donggo sudah tumbuh sejak lama dalam kehidupan mereka, dimana masyarakat Kecamatan Donggo sangat kental dengan tradisi kekeluargaan dan gotong royong. Ketika pada saat ada kegiatan social, seperti memperbaiki rumah, acara pernikah, dan acara-acara yang lainnya mereka akan meninggalkan aktivitas pribadinya demi kepentingan bersama. Jadi dengan kegiatan-kegiatan tersebut akan mempererat hubungan silaturahi antara agama yang satu dengan yang lainya.

Dalam umat beragama terdapat norma sosial, norma agama, norma adat, norma hukum, norma-norma yang terdapat dalam umat beragama berfungsi untuk mengatur kehidupan masyarakat agar tidak terjadi perpecahan, pelecehan atas nama agama, konflik, pembunuhan dan sebagainya. Umat beragama adalah orang-orang yang mengerti dan memahami arti kehidupan tapi tidak semua umat beragama yang memahami kehidupan, ada juga orang atau seseorang yang beragama untuk tampil beda dengan umat beragama yang lain.

\section{METODE PENELITIAN}

Pengumpulan data mengenai pelestarian budaya kaco'i angi atau toleransi pada masyaraat Donggo dilakukandengan cara pastisipatoris aktions dengan terjun langsung dilapngan untuk melihat langsung tentang budaya kaco'l angi pada masyarakat Donggo.Dengan cara ini diharapkan bisa tergambar generalisasi pola budaya aco'I angi yang terjadi pada masyarakat Donggo dalam hubungan antar umat bergama. Hubungan yang dimaksud berkaitan dengan tingkat keintiman(intimacy)ataubahkansebaliknya kebencian yang menyertainya. Dengan kata lain, kaco'i angi atau toleransi dalam hubungan antarumat beragama ini akan dilihat seberapa jauh para pemeluk agama menentukan jarak sosial mereka terhadap para pemeluk agama lainnya. Selain mengukur jarak sosial yang mencerminkan toleransi umat beragama di masyarakat Donggo, penelitian ini juga menekankan pada peran pemerintah serta harapan masyarakat terhadap pemerintahsebagaihalyangdinilai penting untuk mengetahui seberapa besar anggapan dan harapan masyarakat terhadap peran pemerintah dalam memeliharakondisi kerukunan antarumat beragama. Pemerintah sebagai pihak yang memiliki kewenangan formal untuk mengatur hubungan-hubungan sosial, termasuk di dalamnya hubungan antarumat beragama, menjadi aktor yang berperan strategis untuk mendukung terciptanya toleransi yangkondusif.

Data dalam penelitian ini dikumpulkan dengan menggunakan banyak teknik yakni observasi, wawancara dan dokumentasi. Data atau informasi yang diperoleh dalam penelitian ini berasal dari hasil: 1) observasi dilakukan dengan mengamati tempat penelitian secara langsung, 2) Wawancaraterhadap terhadapa tokoh-tokoh dan pemerintah. 3) Dokumentasi semua tahapan penelitian yang dilakukan.

Data yang diperoleh dengan wawancara, wujud data yang diperoleh berbentuk centangan, lingkaran, dan kalimat jawaban yang diberikan oleh informan (interviewee) dan dicatat oleh pengumpul data atau peneliti/evaluator. Observasi dilakukan di masyarakat Donggo. Data-data mentah di atas berikutnya disajikan/diolah untuk memudahkan pemaknaan/penafsiran terhadap data itu sendiri sehingga proses analisisnya menjadi lebih reliabel dan valid. Penyajian/pengolahan data mentah tersebut dilakukan melalui tiga tahapan, yakni tabulasi data, analisis data dan triangulasi data. 


\section{HASIL DAN PEMBAHASAN}

\section{Posisi Agama dalam masyarakat Donggo}

Menurut Maclver, masyarakat dibentuk oleh struktur yang tidak kelihatan dan merupakan kumpulan dari beragam hubungan manusia yang dibangun dan diubah oleh manusia itu sendiri( James. D. Proctor, 2005:90). Masyarakat bergerak dinamis sesuai dengan perkembanganjaman. Dalam masyarakat Donggo agama dipahami sebagai alat control dalam aktivitasnya dalam kesehariannya. Sehinggga tidak heran masyarakat Donggo mengajarkan anak-anaknya untuk menuntut ilmu walaupun dengan kondisi ekonomi yang yang tidak memungkinkan, karena menurut leluhurnya lebih baik buta dengan urusan dunia daripada buta tentang ajaran keagamaan. Sehingga animo masyarakat Donggo untuk mendorong anak-anaknya untuk mengaji, shalat dan kegiatankegiatan keagamaan lainnya menjadi prioritas.

Dahulu masyarakat Donggo sangat kental dengan nilai-nilai budaya, dalam hal ini budaya kaco'i angi karena nilai tersebut merupakan cerminan sesorang yang memahami konsep keagamaan yang sempurna. Walaupun pada masyarakat Donggo terdapat tiga agama yang berbeda, namun kehidupan beragamanya sangat harmonis bukan berarati karena ada hubungan darah diantara satu dengan yang lainnya, tetapi lebih pada menguatnya pemaknaan budaya kaco'i angi yang sudah mendarah daging dalam setiap anggota masyarakat Donggo yang di lingkungan masyarakatnya. Inilah yang menarik yang saya temukan pada masyarakat Donggo. Agama bagi masyarakat sudah final, tetapi dalam pengejewantahan nilai-nilainya perlu kecermatan dan kehatihatian demi terwujudnya kehidupan yang aman tentram bagi semua pemeluk agama yang ada didalamnya. Masyarakat Donggo memahami agama orang lain denganperasaan antipati. Toleransi yang dikembangkan dalam masyarakat ini tidak terjalin atau berjalan normal. Mereka mudah tersentuh atau tersinggung bila ajaran keyakinan agama mereka sepertinya dihina oleh pemeluk agama lain. Mereka merespon langsung dengan mempertahankan taruhan jiwa. Mereka memahami agama orang lain dengan sikap antipati.

Karakter interaksi antar kebudayaan dalam masyarakat multikultural adalah terjadinya asimilasi kebudayaan. Begitu juga dalam hal keberagamaan. Orang-orang yang hidup dalam masyarakat multikultural berasimilasi mengenai bagaimana keberagamaan yang baik dalam masyarakat dengan komposisi kepemelukan agama yang heterogen. Beda halnya dengan masyarakat Donggo dalam hubungan sosialnya tetap menjunjung tinggi nilai-nilai persaudaraan. Hal ini menciptakan rasa toleransi dan kerjasama antar budaya-agama. Proses asimilasi ini muncul bukan hanya untuk kelompok minoritas tetapi juga untuk kelompok mayoritas. Mereka beranggapan bahwa masyarakat memiliki struktur moral dan kebudayaan yang padu dan koheren. Hal seperti ini jarang menjadi permasalahan. Meskipun struktur moral dan kebudayaan masyarakat memiliki koherensi internal, struktur itu tidak sepenuhnya sama dan padu. Struktur tersebut berbeda-beda menurut kelas, agama, wilayah dan disusun dari bermacam-macam rangkaian pemikiran bahkan yang bertentangan serta terdiri dari nilai-nilai dan praktek-praktek yang dapat ditafsirkan dan dihubungkan dengan beberapa cara yang berbeda. Golongan assimilasionis mengabaikan semua ini dan menawarkansatu

\section{Posisi Kaco'i angi pada masyarakat Donggo}

Dalam masyarakat Donggo kaco'i angi menjadi hal yang sangat urgen dalam kehidupan, karena kita budaya kaco'i angi ini hilang atau pudar maka dipastikan akan timnul berbagai macam persoalan ataupun gejolak yang tidak diinginkan dalam kehidupan. Budaya kaco'i angi dapat terlihat pada sikap seorang anak pada orang tuanya, sikap adik pada kakak-kakanya, anak muda pada orang dewasa, siswa pada gurunnya dan masih banyak yang lainnya. Ketika nilai budaya ini hilang, maka jangan heran terjadi pelecehan, perkelahian sampai pada pembunuhan yang terjadi diakibatkan oleh karena nilai-nilai luhur kebudayaan tidak dijadikan sebagai pijakan dalam kehidupan bermasyarakat. Pantaslah budaya kaco'i angi perlu dipertahankan dan dilestarikan untuk membentengi anggota masyarakat bertindak yang tidak sesuai dengan nilai-nilai luhur kebudayaan. 
Walaupun dengan perkembangan teknologi hari ini yang begitu kuat mana kala budaya kaco'i angi sudah tertanam kuat dalam diri setia anggota masyarakatnya, maka kemungkinakemungkinan yang menjadi ancaman pudarnya nilai luhur kebudayaan akan dengan mudah tercounter dengan baik. Munculnya konsepmultikultural yang identik dengan masyarakat serba majemuk baik dalam politik, budaya atau bahkan agama, manusia beragama cenderung mengalami konflik akibat adanya berbagi kepentingan yang dihadapinya. Bukan menjadi alasan masyarakat Donggo untuk melepaskan begitu saja nilai-nilai yang ada dan mengikuti trend kebudayaan yang baru, tetapi justeru nilai budaya kaco'i angi perlu dilestarikan dan dipertahankan serta diekspos lewat tindakan-tindakan ril bagi masyarakat Donggo secara internal maupun eksternal. Karena bagi masyarakat Donggo nilai budaya kaco'i angi merupakan jawaban akurat bagi berbagai masalah yang ada mulai dari masalah dalam keluarga sampai pada masalah negra hari ini.

Kaco'i angi atau toleransi beragama yang dilakukan dengan penuh kesadaran akan melahirkan sikap inklusif umat bergama. Sikap ini menganggap agama sendiri benar tetapi masih memberikan ruang untuk menyatakan kebenaran agama lain yang diyakini benar oleh umatnya. Sikap inklusif umat beragama akan mampu meruntuhkan sikap ekstrimis dan eksklusif umat beragama, yang biasanya melahirkan pema- haman fanatik buta dan radikalisme bahkan terorisme yang abadi terhadap umat berbeda agama.

Kaco'i angi itu cukup mensyaratkan adanya sikap membiarkan dan tidak menyakiti orang atau kelompok lain, baik yang berbeda maupun yang sama. Toleransi ditumbuhkan oleh kesadaran yang bebas dari segala macam bentuk tekanan atau pengaruh serta terhindar dari hipokrisis. Toleransi mengandung mak- sud untuk memungkinkan terbentuknya sistem yang menjamin keamanan pribadi, harta benda dan unsur-unsur minoritas yang terdapat dalam masyarakat. Ini direalisasikan dengan menghormati agama, moralitas dan lembaga- lembaga mereka serta menghargai pendapat orang lain dan perbedaan-perbedaan yang ada di lingkungannya tanpa harus berselisih dengan sesamanya hanya karena berbeda keyakinan atau agama. Dalam kaitan dengan agama, toleransi mencakup masalah-masalah keyakinan pada diri manusia yang berhu- bungan dengan akidah atau yang berhubungan dengan ketuhanan yang diyakininya. Seseorang harus diberikan kebebasan untuk meyakini dan memeluk agama (mempunyai akidah) masing-masing yang dipilihnya serta memberikan penghormatan atas pelaksanaan ajaran-ajaran yang dianut ataudiyakininya.

\section{Pelestarian Nilai Budaya Kaco'i Angipada Masyarakat Donggo}

Dari banyak ragamnya budaya kaco'i angi pada masyarakat, berikut adalah bentuk pelestarian nilai budaya yang dimaksud;

a. Mengajak untuk berbuat kebaikan tanpa harus melakukan tindakan yang sifatnya koersif

b. Tidak saling menjatuhkan dengan cara mencela atau menghina aturan dan ajaran agama satu dengan yang lainnya.

c. Bergotong royong dalam membangung tempat peribadatan.

d. Selalu mengingatkan satu sama lain untuk tetap taat terhadap ajaran agama yag telah ditetapkan.

e. Saling menghormati semua ajaran kepercayaan umat agama lain.

f. Menyelesaikan semua persoalan dengan cara musyawarah.

g. Tidak mempersoalkan aliran kepercayaan yang dianut oleh agama lain.

h. Selalu berbagi dan mengajak teman-teman yang berbeda agama ke rumah pada saat hari raya.

Dengan demikian nilai dasar kaco'i angi pada masyarakat Donggo benar-benar sudah tertanam kuat dalam diri setiap anggota masyarakatnya, sehingga kehidupan yang rukun dan harmoni bisa dirasakan oleh setiap masyarakatnya baik yang beragama islam maupun agama lainnya. 


\section{KESIMPULAN}

Kaco'i angi atau toleransi beragama tidak mesti seseorang yang telah memilikikepercayaan akan agamanya lantas beralih ke kepercayaan yang lain dengan anggapan supaya saling menghormati antar umat beragama, tidak juga diartikan sebagai pengakuan kebenaran semua agama yang ada atau disebut pluralisme, sehingga dalam dirinya terdapat kebenaran yang diyakininya sendiri menurut suara hatinya sendiri yang tidak diperoleh atas dasar paksaan orang lain atau diperoleh dari agama. Di dalam perjalanannya, agama-agama yang muncul dalam masyarakat multikultural kemudian dipahami oleh umatnya. Di antara mereka, ada yang memahaminya secara rasional dan ada pula yang memahami- nya secara irrasional atau mistis. Sehingga dengan nilai budaya Kaco'i angi yang dimaksud supaya tidak mengganggu kenyamanan penganut agama lain dan juga tidak menganggap kepercayaan yang diyakini sama dengan penganut agama lain. Untuk menumbuhkan sikap kaco'i angi atau toleransi beragama yang proposional dalam masyarakat multikultural perlu menumbuhkan sikap simpati dan empati dalam setiap anggota masyarakatnya. Dengan begitu kerukunan dalam umat beragama bisa tercapai secara maksimal.Secara garis besar ada tiga model penerapan nilai budaya kaco'i angi antara lain; Pertama; Penerapan budaya kaco'i angi atau toleransi beragama melalui pendidikan religiusitas sehingga dalam penerapanya masyarakat mampu memahami dan mengerti agama-agamalain. Kedua; Penerapan toleransi beragama dalam bentuk pemahaman keanekaragaman sehingga siswa mampu bersikap dalam menghadapi keanekaragaman, bahwa keanekaragaman bukanlah hal yang patut untukdipersoalkan. Ketiga; Penerapan toleransi beragama dalam bentuk cara bersikap terhadap agama lain. Sudah ditanamkan mengenai cara bersikap terhadap agama lain sehingga anggota masyarakat mampu menerapkanya dalam kehidupan sehari-hari yaitu dengan menghormati orang lain yang sedang menjalankan ibadahnya.

\section{DAFTAR PUSTAKA}

Ahmad, Saebani Beni, 2007. Sosiologi agama kajian tentang perilaku institusi dalam bragama anggota persis dan Nahdlatu Ulama. Bandung. PT Refika Aditama

Amin Abdullah Amir. 2011. Rekonstruksi Metodologi Studi Agama dalam Masyarakat. Jakarta: Raja Wali Pers.

Mujani Saiful, 2007, Muslim Demokrat: Islam, Budaya Demokrasi, danPartisipasi Politik di Indonesia Pasca Orde Baru, Jakarta: Gramedia Pustaka Utama.,

Munawar Said Agil Al. 2003. Fiqih HubunganAntar Agama, (Jakarta:Ciputat Press.

Poerwadarminto W. J. S. 1986. Kamus Umum Bahasa Indonesia. Jakarta:Balai Pustaka. Misrawi Zuhairi.2007. Alquran Kitab Toleransi. Jakarta : Pustaka Oasis.

Raho Bernaard, SVD, 2007. Teori sosiologi moderen, Yogyakarta Prestasi Pustaka Publisher;

Silfian Hanani. 2013. Sosiologi pendidikan keindonesia. Jogjakarta: Ar-Ruzz Media

Wahbah Azz Zuhailin 2005. Kebebasan dalam islam. Jakarta Timur: Pustaka Al-Kautsar

Yosef, Lalu. (2010). Makna Hidup dalam Terang Iman Katolik. Yogyakarta: Kanisius.

\section{Sumber Jurnal}

Casram. (2016). Membangun Sikap Toleransi Beragama Dalam Masyarakat Plural. Jurnal IImiah Agama dan Sosial Budaya 1, 2 (Juli 2016): 187-198

Farida. (2013). Toleransi Antar Umat beragama masyarakat Perumahan. Jurnal IImiah Komunitas Unnes. Vol 5, No 1 (2013).

Mahaliya Nahariyanti. (2013). Kerukunan Umat Beragama. blogspot.com/2013/01/kerukunan-umatberagama.html

Rina Hermawati, Caroline Paskarina, Nunung Runiawati. (2016). Toleransi Antar Umat Beragama di Kota Bandung. Volume 1 (2) Desember 2016 eISSN 2528-1569 pISSN 2528-2115

http://elearning.gunadarma.ac.id/doemodul/agama_islam/bab8-Kerukunan_antar_ beragama.pdf 